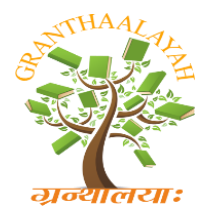

INTERNATIONAL JOURNAL OF RESEARCH GRANTHAALAYAH

A knowledge Repository

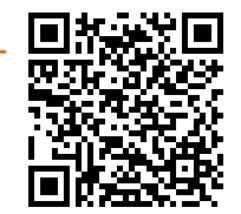

Social

\title{
COFFEE AND COTTON BULK PURCHASE IN TANZANIA, 1939 - 1954
}

\author{
Dr. Somo M.L. Seimu ${ }^{* 1}$ \\ ${ }^{* 1}$ A Lecturer, Moshi Co-operative University, Moshi Tanzania
}

\begin{abstract}
This paper examines bulk purchase of coffee and cotton during the war and post- Second World War period under the long-term contract arrangements as provided under the Defence Ordinance and Orders of 1939, 1940 and 1943 as well as review of various Colonial policies, annual reports, meeting minutes, memoranda and circulars on coffee and production and marketing. Evidence for this topic have been extracted from Tanzania National Archive (TNA) primary sources. It analyses the consequences in employment of administrative machinery, such as the marketing boards, traders and co-operatives in execution the contracts agents on behalf of the British Ministry of Food and Supplies to growers.
\end{abstract}

Keywords:

Tanzania; Kagera; Kilimanjaro; WCGA; bulk purchase; coffee; cotton.

Cite This Article: Dr. Somo M.L. Seimu, "COFFEE AND COTTON BULK PURCHASE IN TANZANIA, 1939 - 1954" International Journal of Research - Granthaalayah, Vol. 4, No. 4 (2016): 137-151.

\section{INTRODUCTION}

This paper examines bulk purchase of coffee produced by small scale native growers in Kilimanjaro and Kagera regions in Tanzania; and cotton produced by small scale native growers in the Western Cotton Growing Area (WCGA) that comprised of Mara, Mwanza, Simiyu and Shinyanga regions. A choice of this topic is motivated by a limited interest shown or complete neglect in the existing literature. For example by Yoshida, ${ }^{1}$ and Leubuscher ${ }^{2}$ made an attempt to compare coffee marketing in Kagera and cotton in the WCGA in relation to development in Uganda. However, both they lack insignificant development in Kagera and WCGA. Whereas, coffee marketing in Kilimanjaro is altogether neglected for example, Yoshida hardly provides a detailed account of development and that fails to justify its conclusion on Tanzania. Ruthenberg discusses agricultural development during British colonial rule. ${ }^{3}$ His work offers relevant and useful ideas on such policies. However, Ruthenberg coverage of policies is too general and lacks specificities particularly where and why cash crop production and marketing policies were applied. Authors such as Philip Curtin, ${ }^{4}$ Owusu ${ }^{5}$ Tosh also, Kelemen, Meredith and Sunderland have published their findings on cash crop production, ${ }^{6}$ with a focus on Sub Saharan Africa but, with limited emphasis on Tanzania. 


\section{METHODS AND MATERIALS}

In an attempt to fill the identified gap this paper extensively underutilised primary materials that includes review of various Colonial Office $(\mathrm{CO})$ policies, memoranda and circulars on agricultural crop production and marketing obtained from Tanzania National Archive (TNA) in Dar Es Salaam that provides policy evidences. Other materials includes the colonial government's agriculture Annual Reports, Policies, Memoranda, Orders, meeting minutes and Circulars on agriculture, agricultural marketing legislations as well as the Provincial and district reports. The evidence from mentioned sources were employed provides a detailed account of agreements between with Ministry of Food and Marketing Boards also traders in Tanzania from time of outbreak of Second World War to 1950s when the agreements came to an end. In considering this topic a review of literature was conducted.

\section{COFFEE PRODUCTION IN KILIMANJARO AND KAGERA}

Historically, the colonial authority encouraged small-scale growers to cultivate coffee and cotton. Both crops were introduced to the small scale native growers during the German colonial and Tanzania was handed to the British in 1922 under the League of Nations Mandate Agreement. The encouragement of the small-scale growers to produce coffee and cotton for commercial purposes began in 1916 immediately when the regions fell to the British hands. The motivation for encouraging small-scale growers was to attain territorial financial self-sufficiency.

Coffee production in Kilimanjaro among small scale growers was basically voluntary in which the local chiefs (Mangi) mobilised and enforced of coffee farming practices among its subjects. This was contrary for coffee farming in Kagera region where small-scale native growers were forced to plant coffee in which each household was required to plant 100 seedlings with seedlings being made available by the colonial authority. ${ }^{7}$ This was initiated and enforced by Denis Lynch Baines, ${ }^{8}$ the British Administrator when the district came under the British rule in 1916. ${ }^{9}$ The colonial authority introduced a series of Ordinances, Regulations and Orders in 1927 geared towards coffee improvement and better husbandry. These increased the degree of coercion enforced by the chiefs and headmen who were also coffee growers. Similarly, the Chiefs were made responsible cotton compulsory cultivation enforcement policy such as a minimum acreage in the WCGA provided under the Cotton Ordinance. ${ }^{10}$

\section{COFFEE MARKETING KILIMANJARO AND KAGERA}

In Kilimanjaro native organisations, were granted coffee marketing monopoly the KNPA from 1929. Following the reorganisation of the KNPA under the co-operative legislation the monopoly was granted to the KNCU from 1934 provided under the Chagga Rule and the 1937 native coffee control and marketing legislation. Such policy resulted in the displacement of the trading population (Indian traders) from Kilimanjaro.

However, coffee and marketing in Kagera region and cotton in the WCGA were influenced by a number of factors. These two areas are located around Lake Victoria in North West Tanzania. When the British took over, this location was remote from Tanga and Dar-Es-Salaam ports. The existing roads were poor and railway transport was not in existence until 1928 when a line 
connecting Mwanza and Dar-Es-Salaam was built. Before the railway link to Dar Es Salaam, export from these two locations was by steamships to Kisumu and then by train to Mombasa. Thus, they were remote from Tanga and Dar Es Salaam ports and had some challenges in administering agricultural policies. Since they had geographical proximity advantage with Uganda, Kagera and WCGA were always utilized its outlets through Uganda then to Mombasa. To this effect, it became essential to maintain a parallel scheme with Uganda under which the Tanganyika government had to mandate the Ugandan government to dictate marketing policy for coffee and cotton produced in Kagera and the WCGA respectively. ${ }^{11}$

Some of traders like Sheriff Jiwa and many other moved its coffee marketing to Kagera that increased a number of Indian traders in the region where through the Chamber of Commerce successfully managed to influence the colonial authority to disregard the promotion of cooperative marketing societies in the region which they regarded the co-operative movement as a barrier to free trade. It has to be noted that by 1932 the co-operative legislation was in place. But, the colonial officials in the region did not consider using the legislation as the basis for strategising the promotion of co-operative movement in the region. Instead, the colonial authority encouraged coffee free trade in Kagera region that attracted Indians and Arabs traders in the region where they organised the local trade and coffee exports. The natives were not segregated in coffee marketing hundreds were issued with licensed to purchase coffee under which wide spectrums of family members are involved either as traders themselves or as employees or agents of Indian traders.

The coffee collection and marketing networks in the village were managed by the abalanguzi be emwani i.e. itinerants coffee traders who were hired to collect coffee from households in some Gombolola in Kianja, Ihangiro, Kiziba, Kaimatwara, Bugabo, Kanyengereko, Karagwe and Misenyi Chiefdoms in Kagera region as summaried in Table 1 below.

Table 1: Licensed Coffee Dealers in some Bukoba Region

\begin{tabular}{llllll}
\hline Gombolola & Europeans & Indians & Arabs & Africans & Total \\
\hline Kianja & 2 & 50 & 34 & 81 & 45 \\
Ihangiro & - & 24 & 23 & 36 \\
Kiziba & - & 13 & 7 & 14 \\
Kiamtwara & - & 24 & - & 14 \\
Bugaboo & - & 1 & - & 23 \\
Kanyengereko & - & 3 & 1 & 1 \\
Mnazi & - & - & - & 8 \\
Ibuga & - & - & - & 3 \\
Izigo & 1 & 3 & 2 & 14 \\
Mikoni & - & - & - & 9 \\
Kaibanya & - & 8 & 8 & 81 \\
Total & 2 & 50 & 34 & (Appendix H), TNA 24545 \\
\hline Source: R.C. Northcote, Bukoba Coffee Industry in Report on Bukoba Coffee Marketing, (A)
\end{tabular}

Source: R.C. Northcote, Bukoba Coffee Industry in Report on Bukoba Coffee Marketing, (Appendix H), TNA 24545

The abalanguzi were a vital network as they lived within a village and occupied an important place as were well-known to growers. Additionally, coffee marketing in the region was 
controlled from Uganda which was mandated by Tanzania colonial authority to manage the industry in the region owing to geographical proximity and transport infrastructure. Just as in Uganda Indian agents, mainly from Mombasa and Uganda, controlled the export of coffee. ${ }^{12}$

As a result, the coffee free trade in Kagera suffered one critical challenge, poor quality. The quality was compromised due to an intensive struggle among the traders and laxity in control as from the colonial authority as there was no legal institution empowered for quality assurance. Concerned by this the colonial authority in the district and province invited Mr R.C. Northcote, the Co-operative Registrar to investigation which established that marketing 'was in far worse state'. ${ }^{13}$ Thus, he recommend to establishment of coffee marketing control board. This coincided with the promulgation of the Native Coffee (Control and Marketing) Ordinance No. 26 of 1937 that provided for control of coffee produced by Africans in Kilimanjaro that provided for the formation of the Moshi Native Coffee Board (MNCB) in 1937 and the Bukoba Native Coffee Board (BNCB) in April $8^{\text {th }} 1941$.

\section{COTTON PRODUCTION AND MARKETING IN THE WCGA}

Since 1920s a number of traders flocked in the WCGA where they managed to monopolise cotton purchase from growers at established/centralised where they had a monopoly in cotton marketing and engaged in ginning. ${ }^{14}$ Some of them were the British Cotton Growing Association (BCGA) which was conducting its businesses in Nyambiti and Nyanguge in Kwimba district and one in Biharamulo district, Missionaries (White Fathers) at Ukerewe and Indian were in all district in the WCGA as summaries in Table 2 below.

Table 2: The Ginneries, Year of Installation and Ownership in the WCGA

\begin{tabular}{lll} 
Manawa & 1924 & Indian \\
\hline Nassa & 1924 & Indian \\
\hline Nyambiti & 1935 & Indians and BCGA \\
\hline Nyamililo & 1930 & Indians and BCGA \\
\hline Ukerewe & 1932 & Indian and White Fathers \\
Luguru & 1933 & Indian \\
Malampaka & 1933 & Indian \\
Uzogole & 1940 & Indian \\
Kibara & 1952 & Indian \\
Mugango & 1936 & Indian \\
\hline
\end{tabular}

Source: Tanganyika Territory Annual Reports on Co-operative Development, (Dar Es Salaam: Government Printer, 1955), pp.911

The domination of mentioned traders of the cotton marketing was obvious because the growers had no knowledge of cotton markets beyond their villages or neighbouring towns and they had no capital. The quality control was limited as the inexperienced Native Authorities were assigned cotton quality assurance. ${ }^{15}$ However, the system proved a failure because as cotton quality was compromised prompted by poor price that traders paid the growers; importantly, indiscriminate buying and uneconomic competition was widespread that had adverse effect cotton quality. For example, cotton below the government recommended price and cheating of growers was 
widespread; ${ }^{16}$ all these partly demoralised grower participation in cotton production. ${ }^{17}$ The situation prompted intervention by the colonial in 1923 and through 1930s provided under the 1931 Cotton Ordinance and its 1933 amendments that led to the reorganisation purchase and licensing that confined buyer's operation to a specific production zone. ${ }^{18}$

Immediately after the outbreak of the Second World War the British Secretary of State for the Colonies ordered to embark into bulk purchasing arrangements for coffee and cotton from Tanzania in order to keep the supply of food and raw materials supply stable provided under the bulk purchase short and long-term contracts as discussed in the following section.

\section{THE BULK PURCHASING ARRANGEMENTS}

At home, the British government instituted rationing to help maintain stocks of supplies and price control was put in place to protect consumers from being exposed to profiteering. ${ }^{19}$ Tanzania and East African colonies of Kenya and Uganda were expected to contribute to the war effort by supplying food and raw materials. This was carried out by the Ministries of Food and Supply in collaboration with the $\mathrm{CO}$ and colonial authorities on behalf of the colonial power. The colonial authorities appointed agents to handle food and raw materials supply in the colonies. ${ }^{20}$ In East Africa an inter-government Joint Economic Council was set up to co-ordinate purchase of crops and raw materials. The Council was formed following the publication of a Circular by the Colonial Office (CO) in 1939 that emphasised the need for a uniform policy and collaboration between groups of British colonial territories based on geographical locations for example, East Africa, West Africa. ${ }^{21}$

The measure was seen significantly important as British economy was critical in 1942-3, for example, in 1942 it began losing her Asia colonies to Japan expansionism and occupation; the Suez Canal was almost captured by the enemy that jeopardised its trade route to India and its economic strategies were also under threat. All these posed a critical threat in a loss of important sources of raw materials. Hence, government control and supervision of the economy increased because of the necessity to organize production for war efforts.

\section{THE COFFEE BULK-PURCHASE CONTRACTS}

The native coffee industry in Tanzania was included in bulk purchase under long term contracts and the produce was sold to the Ministry of Food and Supply which had exclusive control of food and raw materials imports in Britain. The colonial authority in Tanzania just as in other British colonies had to adjust its marketing policies and established the administrative machinery to provide for the supply of commodities under bulk purchase agreement. Under the legislation coffee and cotton produced by the native small scale growers with that effect had to be compulsorily sold to the British Ministry of Food through the recommended outlets, mainly marketing boards. Against this background, coffee and cotton supplies were secured from the level of growers in the colonies to consumers in Britain through the bulk-purchase contracts under the Defence Ordinance and Orders of 1939 and 1940, which reinforced the existing coffee and cotton control and marketing. 
Bulk-purchase was characterised by short, medium or long-term contracts with producers in the colonies through marketing boards or co-operative societies in which purchase was in fixed quantities; and prices, which were low were fixed and reviewed on a year-to-year basis ${ }^{22}$ as per Section 7 of the contract. ${ }^{23}$ Under the contract between 1940 and 1952, the MNCB supplied coffee to the Ministry of Food. The KNCU also became an agent for the Ministry of Food during this period and was required to supply 4,000 tons. ${ }^{24}$ The Ministry of Food was responsible for setting prices for commodities bought from grower; for example, coffee produced by African growers was between 80/- to 105/- shillings whereas by settlers or non-natives and natives in Southern Highland, Tanga and Northern Provinces who were served by associations ${ }^{25}$ affiliated to the Tanganyika Coffee Growers Association (TCGA) was between $£ 125-150$ per ton. ${ }^{26}$ The TCGA was appointed as the agent of the Mild Coffee Board to handle coffee from its members which was sold to the Ministry of Food. ${ }^{27}$

The Ministry of Food approached the KNCU for an extension of the contract when it expired in the early 1950s as provided by Section 7 of the long-term contract; but it was declined. The KNCU declined because price determined by the Ministry of Food inflicted a loss on growers who were paid 80 per cent of the freight on board (fob) value of their coffee after deduction expenses, taxes, levies under which they earned only $£ 30$ annually. ${ }^{28}$ This indicates that the KNCU was not prepared for any further loss and were determined to ensure that growers enjoyed a profit for coffee cultivation. Significantly, under clause 14 of the long-term contract, price could be revised in the view of devaluation of sterling $;{ }^{29}$ but the Ministry of Food was prepared to pay only two thirds of the free market price during $1951 / 52,30$ The KNCU declined owing to the depreciation of sterling and preferred to sell in more profitable dollar markets. ${ }^{31}$

In 1951 the Defence Orders were revoked as they were deemed no longer necessary. ${ }^{32}$ It has to be recalled that, during the time compulsion policies that provided for a relaxation export and price control $^{33}$ and setting up of auctions in Moshi in 1953 where KNCU coffee was sold. All these developments took place when Conservative government took power in $1951 .{ }^{34}$ The Conservative policy was against restrictive Labour Party's policies, including rationing. ${ }^{35}$ It championed a reduction in state intervention in the economy.

Following the outbreak of the Second World War, the Bukoba Coffee Control Board (BCCB) and later BNCB with effect from 1942 charged with supplying coffee to the Ministry of Food under a long-term contract under the Defence Ordinance and Orders of 1939 and 1940. The Bukoba Coffee Control Board (BCCB) which supplied 4,000 tons of coffee $^{36}$ as provided under Section 7 of the contract. ${ }^{37}$ The evidence shows that such price for Robusta produced in Kagera which was pegged at a price not less than $£ 60$ and not exceeding $£ 75 .{ }^{38}$ In an attempt to ensure supply of coffee was maintained, marketing zones were set up and agents were appointed to handle coffee from growers (see Table 8 below). However, Coulson in his work has indicated that, the agents and these zones were created in $1954^{39}$ which is incorrect. It has to be noted that, the agents licence expired in 1954 when the coffee purchase contract between the Board and Ministry of Food expired. This was in compliance with the CO's policy regarding crop marketing which was published in June 1937 in which it was stressed that local agencies should to be involved. This contributed to a fading away of interest in co-operative societies. For agents, co-operatives meant deprivation of the opportunity that they enjoyed over the years. 
Britain presented a proposal for extension of the bulk purchase contract for a supply of coffee which was about half of the British home needs up to $1954^{40}$ which was 2,000 tons of Robusta coffee to Ministry of Food for 1952/53 and the same tonnes for $1953 / 54^{41}$ on much the same price terms as previous contracts. The remaining stock was sold in auctions and Robusta was sold $£ 100$ per ton contrary to $£ 65$ on the same weight paid by the Ministry of Food. ${ }^{42}$

\section{THE COTTON BULK-PURCHASE CONTRACTS}

After the outbreak of WWII, an Export Group was appointed to handle the crop on behalf of the colonial government and the Ministry of Food. The measure was not only to ensure supply of cotton to Britain but also marketing of growers' produce. These developments demonstrate that growers had no stake in the marketing of their produce. This was marked policy shift in agriculture marketing from inter-war marketing strategies discussed earlier. This was geared to suit the colonial power interventions and control of agriculture marketing following the outbreak of WWII in 1939 to 1950s cotton was also subjected under the Defence (Control of Cotton) Regulation of $1939,{ }^{43} 1942$ and $1943^{44}$ under which the Colonial Office assured the Colonial government in Tanganyika ${ }^{45}$ that it was committed to purchase 45,000 bales of cotton from WCGA $^{46}$ at a fixed price of $12 /$ - shillings (£10) per a bale for a five year contract. ${ }^{47}$

In the WCGA there was no control Board for cotton as there was for coffee, thus the DA had to assume the role of Cotton Controller. A Cotton Advisory Board, which was set up in 1927, which was charged with responsibility for approving and issuing of the cotton marketing licenses. ${ }^{48}$ The co-ordination of marketing was handled by the East African Exporters Group, ${ }^{49}$ which was set up by the colonial government as the administrative machinery designed for execution of the contract arrangements. The Exporters Group came into long term agreement with the Ministry for purchase of the whole cotton crop produced in the Lake Province/WCGA ${ }^{50}$ on fixed price of 12 cents per $\mathrm{lb}$ in $1943 .^{51}$ By 1950 this had risen to 34 and by 1960 to 54 cents per $1 b^{52}$ and it was increase to 1.06 shillings for AR grade and 0.51 cents for BR grade by $1968 .^{53}$

The administrative machinery to handle cotton exports during and post-war years was reinforced by a cotton marketing policy that did not consider promotion of the co-operatives. Instead, it reinforced the East African Exporters Group role in handling cotton. The position of the East African Exporters Group in Uganda was weakened following the setting up of the Lint and Seed Marketing Board (LSMB) which, took over the Group's functions in 1949. ${ }^{54}$ Ugandan Cotton Board handed over its functions to Tanzanian Board in 1952 following its formation which was provided under the Lint and Seed Marketing Ordinance No. 11 of 1952 that provided for setting up of the LSMB in April $1^{\text {st }} 1952$ with John Ballemy as its first Manager. This was a year when supply of cotton on contract basis to Britain came to an end. However, the until the Board 1958 exported Tanzania's cotton through the Uganda Cotton Board that is why the Victoria Federation of Co-operative Unions (VFCUS) could not be appointed as agent just the same of the KNCU until when it acquired the export status with effect from 1959.

After the outbreak of WWII, an Export Group was appointed to handle the crop on behalf of the colonial government and the Ministry of Food. The measure was not only to ensure supply of cotton to Britain but also marketing of growers' produce. These developments demonstrate that 
growers had no stake in the marketing of their produce. This was marked policy shift in agriculture marketing from inter-war marketing strategies discussed earlier. This was geared to suit the colonial power interventions and control of agriculture marketing following the outbreak of WWII in 1939 to 1950 s cotton was also subjected under the Defence (Control of Cotton) Regulation of $1939,{ }^{55} 1942$ and $1943^{56}$ under which the Colonial Office assured the Colonial government in Tanganyika ${ }^{57}$ that it was committed to purchase 45,000 bales) of cotton from WCGA $^{58}$ at a fixed price of $12 /$ - shillings (£10) per a bale for a five year contract. ${ }^{59}$

In the WCGA there was no control Board for cotton as there was for coffee, thus the DA had to assume the role of Cotton Controller. A Cotton Advisory Board, which was set up in 1927, which was charged with responsibility for approving and issuing of the cotton marketing licenses. ${ }^{60}$ The co-ordination of marketing was handled by the East African Exporters Group, ${ }^{61}$ which was set up by the colonial government as the administrative machinery designed for execution of the contract arrangements. The Exporters Group came into long term agreement with the Ministry for purchase of the whole cotton crop produced in the Lake Province/WCGA ${ }^{62}$ on fixed price of 12 cents per lb in $1943 .{ }^{63}$ By 1950 this had risen to 34 and by 1960 to 54 cents per $1 b ;{ }^{64}$ and it was increase to 1.06 shillings for AR grade and 0.51 cents for BR grade by $1968 .{ }^{65}$

The administrative machinery to handle cotton exports during and post-war years was reinforced by a cotton marketing policy that did not consider promotion of the co-operatives. Instead, it reinforced the East African Exporters Group role in handling cotton. The position of the East African Exporters Group in Uganda was weakened following the setting up of the Lint and Seed Marketing Board (LSMB) which, took over the Group's functions in $1949 .{ }^{66}$ Ugandan Cotton Board handed over its functions to Tanzanian Board in 1952 following its formation which was provided under the Lint and Seed Marketing Ordinance No. 11 of 1952 that provided for setting up of the LSMB in April $1^{\text {st }} 1952$ with John Ballemy as its first Manager. This was a year when supply of cotton on contract basis to Britain came to an end. However, the until the Board 1958 exported Tanzania's cotton through the Uganda Cotton Board that is why the Victoria Federation of Co-operative Unions (VFCUS) could not be appointed as agent just the same of the KNCU until when it acquired the export status with effect from 1959.

The colonial authority in Tanzania had to adjust its marketing policies and established the administrative machinery to provide for the supply of commodities under bulk purchase agreement. The native coffee industry in Tanzania was included in bulk purchase under long term contracts and the produce was sold to the Ministry of Food which had exclusive control of food and raw materials imports in Britain. Under the legislation food and raw materials produced by Africans with that effect had to be compulsorily sold to the British Ministry of Food through the recommended outlets, mainly marketing boards. Against this background, the food crop and raw materials, supplies were secured from the level of growers in the colonies to consumers in Britain through the bulk-purchase contracts under the Defence Ordinance and Orders of 1939 and 1940, which reinforced the existing coffee and cotton control and marketing.

Bulk-purchase was characterised by short, medium or long-term contracts with producers in the colonies through marketing boards or co-operative societies in which purchase was in fixed quantities; and prices, which were low were fixed and reviewed on a year-to-year basis ${ }^{67}$ as per 
Section 7 of the contract. ${ }^{68}$ Under the contract between 1940 and 1952, the MNCB supplied coffee to the Ministry of Food. The KNCU also became an agent for the Ministry of Food during this period and was required to supply 4,000 tons. ${ }^{69}$ The Ministry of Food was responsible for setting prices for commodities bought from grower; for example, coffee produced by African growers was between $80 /$ - to 105/- shillings whereas by settlers or non-natives which was sold through the Tanganyika Coffee Growers Association (TCGA) was between $£ 125-150$ per ton. $^{70}$

The Ministry of Food approached the KNCU for an extension of the contract when it expired in the early 1950s as provided by Section 7 of the long-term contract; but it was declined. The KNCU declined because price determined by the Ministry of Food inflicted a loss on growers who were paid 80 per cent of the freight on board (fob) value of their coffee after deduction expenses, taxes, levies under which they earned only $£ 30$ annually. ${ }^{71}$ This indicates that the KNCU was not prepared for any further loss and were determined to ensure that growers enjoyed a profit for coffee cultivation. Significantly, under clause 14 of the long-term contract, price could be revised in the view of devaluation of sterling $;{ }^{72}$ but the Ministry of Food was prepared to pay only two thirds of the free market price during $1951 / 52$ ' ${ }^{73}$ The KNCU declined owing to the depreciation of sterling and preferred to sell in more profitable dollar markets. ${ }^{74}$

In 1951 the Defence Orders were revoked as they were deemed no longer necessary. ${ }^{75}$ It has to be recalled that, during the time compulsion policies that provided for a relaxation export and price control $^{76}$ and setting up of auctions in Moshi in 1953 where KNCU coffee was sold. All these developments took place when Conservative government took power in $1951 .^{77}$ The Conservative policy was against restrictive Labour Party's policies, including rationing. ${ }^{78}$ It championed a reduction in state intervention in the economy.

Under the Native Coffee legislation the Bukoba District Coffee Board (BDCB) was formed under General Notice No 329 of April $8^{\text {th }} 1941$ to oversee coffee produced by the Africans. In 1942 the (BDCB) was replaced by the Bukoba Coffee Control Board (BCCB) which was established under the General Notice No. 329 on April $8^{\text {th }}$ 1941. The BCCB oversaw the cultivation and marketing of the native- produced coffee just the same as MNCB in which the industry was brought under the control of government; and marketing policy for native produced coffee was harmonised. On October 31st, 1947 the BCCB was renamed the Bukoba Native Coffee Board (BNCB).

Following the outbreak of the Second World War the Bukoba Coffee Control Board (BCCB) and later BNCB with effect from 1942 charged with supplying coffee to the Ministry of Food under a long-term contract under the Defence Ordinance and Orders of 1939 and 1940. The Bukoba Coffee Control Board (BCCB) which supplied 4,000 tons of coffee ${ }^{79}$ as provided under Section 7 of the contract. ${ }^{80}$ The evidence shows that such price for Robusta produced in Kagera which was pegged at a price not less than $£ 60$ and not exceeding $£ 75 .{ }^{81}$ In an attempt to ensure supply of coffee was maintained, marketing zones were set up and agents were appointed to handle coffee from growers (see Table 3 below). This was in compliance with the CO's policy regarding crop marketing which was published in June 1937 in which it was stressed that local agencies should to be involved. This contributed to a fading away of interest in co-operative societies. For agents, co-operatives meant deprivation of the opportunity that they enjoyed over the years. 
Table 3: Coffee Marketing Zones, Locations and Appointed Agents in Kagera

\begin{tabular}{llll}
\hline S/N & Zone & Sub - Chiefdoms/Locations & Appointed Agents \\
\hline 1 & Muleba & Kahengere, Bukoba, Ilamera, Mubunda, And Karambo & SherrifJiwa and Co Ltd \\
2 & Nshamba & Kashasha, Mbatama, Kishanda, Nshamba, And Birabo & Messers. M. N. Patel and Co Ltd \\
3 & Kamachumu & Ibuga And Kamachumu & Messers. Rashid Maledina and Co Ltd \\
4 & Muhutwe & Izigo, Muhutwe, Rwagati, and Minazi & J. s. Patel and Co Ltd \\
5 & Ikimba & Kabirizi, Mikoni, Ibweru, Kishogo, and Kaibanja & Messers. Rashid Maledina and Co Ltd \\
6 & Maruku & Kanyangereko Chiefdom & J.S. Patel and Co Ltd \\
7 & Kiziba & Kiziba Chief & Messers. J. S. Patel and Co Ltd \\
8 & Bugabo & Bugabo Chiefdom & Sheriff Jiwa and Co Ltd \\
9 & Kyaka & Misenyi Chiefdom & Messers Shah and Co Ltd \\
10 & Karagwe & Karagwe Chiefdom & Messers Shah and Co Ltd \\
11 & Bukoba & Kyantwara Chiefdom & Mr. KassamaliAllarakhusa and Co Ltd \\
12 & Bumbire & Ihangiro & The BCU \\
\hline
\end{tabular}

Source: BCNB 1948 and 1950 Annual Reports

Britain presented a proposal for extension of the bulk purchase contract for a supply of coffee which was about half of the British home needs up to $1954^{82}$ which was 2,000 tons of Robusta coffee to Ministry of Food for 1952/53 and the same tonnes for $1953 / 54^{83}$ on much the same price terms as previous contracts. The remaining stock was sold in auctions and Robusta was sold $£ 100$ per ton contrary to $£ 65$ on the same weight paid by the Ministry of Food ${ }^{84}$ and led to an escalation in smuggling.

After the outbreak of WWII, an Export Group was appointed to handle the crop on behalf of the colonial government and the Ministry of Food. The measure was not only to ensure supply of cotton to Britain but also marketing of growers' produce. These developments demonstrate that growers had no stake in the marketing of their produce. This was marked policy shift in agriculture marketing from inter-war marketing strategies discussed earlier. This was geared to suit the colonial power interventions and control of agriculture marketing following the outbreak of WWII in 1939 to 1950 s cotton was also subjected under the Defence (Control of Cotton) Regulation of $1939,{ }^{85} 1942$ and $1943^{86}$ under which the Colonial Office assured the Colonial government in Tanganyika ${ }^{87}$ that it was committed to purchase 45,000 bales of cotton from WCGA $^{88}$ at a fixed price of $12 /$ - shillings $(£ 10)$ per a bale for a five year contract. ${ }^{89}$

Crucially, in the WCGA there was no control Board for cotton as there was for coffee, thus the DA had to assume the role of Cotton Controller. A Cotton Advisory Board, which was set up in 1927, which was charged with responsibility for approving and issuing of the cotton marketing licenses. ${ }^{90}$ The co-ordination of marketing was handled by the East African Exporters Group, ${ }^{91}$ which was set up by the colonial government as the administrative machinery designed for execution of the contract arrangements. The Exporters Group came into long term agreement with the Ministry for purchase of the whole cotton crop produced in the Lake Province/WCGA ${ }^{92}$ on fixed price of 12 cents per $\mathrm{lb}$ in $1943 .^{93}$ By 1950 this had risen to 34 and by 1960 to 54 cents per $1 \mathrm{~b} ;{ }^{94}$ and it was increase to 1.06 shillings for AR grade and 0.51 cents for BR grade by $1968 .^{95}$ 
The administrative machinery to handle cotton exports during and post-war years was reinforced by a cotton marketing policy that did not consider promotion of the co-operatives. Instead, it reinforced the East African Exporters Group role in handling cotton. The position of the East African Exporters Group in Uganda was weakened following the setting up of the Lint and Seed Marketing Board (LSMB) which, took over the Group's functions in $1949 .{ }^{96}$ Ugandan Cotton Board handed over its functions to Tanzanian Board in 1952 following its formation which was provided under the Lint and Seed Marketing Ordinance No. 11 of 1952 that provided for setting up of the LSMB in April $1^{\text {st }} 1952$ with John Ballemy as its first Manager. This was a year when supply of cotton on contract basis to Britain came to an end. However, the until the Board 1958 exported Tanzania's cotton through the Uganda Cotton Board that is why the Victoria Federation of Co-operative Unions (VFCUS) could not be appointed as agent just the same of the KNCU until when it acquired the export status with effect from 1959.

\section{CONCLUSION}

The bulk purchase proved economically important and beneficial to the colonial power and a disadvantage to growers. The bulk purchase of coffee and cotton during and after Second World War was implemented through the administrative machinery under the contract arrangements. Under the arrangements, the native produced coffee also cotton was handled by appointed agents. This culminated in extensive state control over the marketing of growers' produce. It was made compulsory that coffee produced by natives should be sold through that board or an agency appointed by the board, which were the co-operatives where they existed and private traders.

\section{REFERENCES}

[1] Masao Yoshida, Masao Yoshida, Agricultural Marketing Intervention in East Africa, (Tokyo: Institute of Developing Economies, 1984).

[2] Charlotte Leubuscher, Marketing Scheme for Native-Grown Produce in African Territories, Journal of the International Institute of African Languages and Cultures, Vol. XII, Number 2, (April, 1939), pp. 163-188; Charlotte Leubuscher, Bulk Buying from the Colonies: A study of the Bulk Purchase of Colonial Commodities by the United Kingdom Government, (London: Oxford University Press, 1956).

[3] Hans Ruthernberg, Agricultural Development in Tanganyika, (Berlin: Sringer-Verlag, 1964).

[4] Philip Curtin, 'The Colonial Economy', In Philip Curtin, Steven Feierman, Leonard Thompson, Jan Vansina, African History: From Earliest Times to Independence, (London: Longman, 1995), pp.446-464.

[5] Maxwell Owusu, Agriculture and Rural Development since 1935, In Ali Mazrui (ed.) Africa Since 1935, (Oxford: James Currey Ltd., 1999).

[6] J. Tosh 'The Cash Crop Revolution in Tropical Africa: An Agricultural Reappraisal', African Affairs, 79, (1980); W.E.F Ward and L.W. White, East Africa: A century of Change 1870 - 1970, (London: George Allen and Unwin Ltd, 1971); Paul Kelemen, 'Planning for Africa: The British Labour Party's Colonial Development Policy, 19201964', in Journal of Agrarian Change, Vol. 1, No. 7, (January, 2007); Michael Havinden and David Meredith, (1993); David Sunderland, Managing British Colonial and Post- 
Colonial Development: The Crown Agents, 1914-1974 (Woodbridge: The Boydell Press, 2007).

[7] C. Harvey (undated), 'Coffee Cultivation in Bukoba', TNA 11969 Vol. II.

[8] Baines was Bukoba DC from 1916 to 1919 and then from October 1920 to February 1923

[9] Bukoba District Book

[10] Maswa DC to PC, Lake Province, Ref. No. 402/3676 of May $16^{\text {th }}$ 1933, TNA 215/665, Vol. I.

[11] The Defence (Control of Cotton) Order of 1944, Section 4.

[12] Northcote 1936 Inquiry Report on Bukoba Coffee Industry in Report on Bukoba Coffee Marketing, TNA 24545, pp.11-12.

[13] Northcote 1936 Inquiry Report on Bukoba Coffee Industry in Report on Bukoba Coffee Marketing, TNA 24545.

[14] DA to CS, Ref. No. 6/5389, July 24 $4^{\text {th }} 1935$, TNA 23218.

[15] DA to CS, Ref. No. 6/5389, July 24 ${ }^{\text {th }}$ 1935, TNA 23218; DC Shinyanga to PC Lake Province, Ref. No. 62/38, February 1936, TNA 23218.

[16] PC Lake Province to DA (copy to CS), Ref. No. 1302/150, August 24 $4^{\text {th }} 1935$, TNA 23218

[17] Popat Ranji to Lake Province PC June 20 1947 and August $19^{\text {th }} 1947$ and Dec 22 $2^{\text {nd }}$ 1947 to Bishop of Mwanza, TNA 215/1423/C; Uzinza Farmers Association to Ibanza (Council of Chiefs), October $2^{\text {nd }} 1950$, TNA 215/1423/A.

[18] Government notice No. 84 of 1931 which were amended in 1933 under Government Notice Number 78

[19] United States Department of Agriculture (USDA), United Kingdom Market for United States Agricultural Products Agriculture Information Bulletin No. 104, (Washington, D. C.: The USA Government Printing Office, 1953), p.2.

[20] Lord Listowel, Commonwealth Future, Fabian Tract 308, (London: The Fabian Society, July 1957), p. 24, TNA 23218.

[21] The CO Circular dispatch, August 23 ${ }^{\text {rd }}$ 1939, TNA 29585

[22] The Long Term Contracts Policy on the United Kingdom Departments and Colonial Agriculture Producer, TNA 25147; Standard Newspaper September $28^{\text {th }} 1948$, TNA 25147.

[23] A Contract on the Local Arrangement for Handing of Ministry of Food Coffee, Director of East Africa Produce Disposal and Supply Council (Nairobi), March 13 ${ }^{\text {th }}$ 1947, TNA 37200.

[24] Extract from minute of meeting of the standing committee held in April 1947, TNA 11969.

[25] Kilimanjaro Coffee Growers Association, Lupembe Plasters Association, Mbeya Mountain coffee Plasters Association, Mbozi Plasters Association, Meru Coffee Growers Association, Oldean Plasters Association, Sanya Ngare-Nairobi Plasters Association, Ufiome Plasters Association, Usambara Plasters Association and Usa River Plasters Association.

[26] DA to CS, Ref. No. C/133/330, December, 17 th 1942, TNA 37200; Ministry of Food to CS, Telegram, No. WB/293, November $21^{\text {st }}$ 1946, TNA 37200.

[27] Tanganyika Territory, Report on Co-operative Development, Dar Es Salaam: Government Printer, 1950), TNA 37192; TCGA Tanganyika Coffee Board: Meetings Agenda and Minutes, TNA 24304.

[28] KNCU to Ministry of Food, TNA 37200. 
[29] East Africa High Commission, London to East Africa Joint Economic Commission (Nairobi) Confidential Telegram, Ref. No. 4142/458, October 28 $8^{\text {th }} 1949$, TNA 37200.

[30] KNCU to Ministry of Food, TNA 37200.

[31] One of the causes for the sterling depreciation in terms of United States of America (USA) dollar was economic slowdown, economic depression in the USA and capital flight in Britain as a result of the Second World War that sterling pound sharply depreciated to $\$ 4.03$.

[32] Tanganyika Legislative Council Debates, Hansard, 1950, $29^{\text {th }}$ Session, para. 241, TNA 37200.

[33] The Decontrol of Coffee, Press Notice by Ministry of Food August 20 th 1952, TNA 37200.

[34] The Decontrol of Coffee, Press Notice by Ministry of Food August 20 th 1952, TNA 37200.

[35] USDA, United Kingdom Market for United States Agricultural Products Agriculture Information Bulletin No. 104, (Washington, D. C.: The USA Government Printing Office, 1953), p.56.

[36] The Long Term Contracts Policy on the United Kingdom Departments and Colonial Agriculture Producer, TNA 25147; Standard Newspaper September $28^{\text {th }} 1948$, TNA 25147.

[37] A Contract on the Local Arrangement for Handing of Ministry of Food Coffee, Director of East Africa Produce Disposal and Supply Council (Nairobi), March 13 ${ }^{\text {th }}$ 1947, TNA 37200.

[38] DA to CS, Ref. No. C/133/330, December, 17 th 1942, TNA 37200; Ministry of Food to CS, Telegram No. WB/293, November $21^{\text {st }} 1946$, TNA 37200..

[39] Andrew Coulson, (1982), p. 66.

[40] The Decontrol of Coffee, Press Notice by Ministry of Food August 20 ${ }^{\text {th }}$ 1952, TNA 37200.

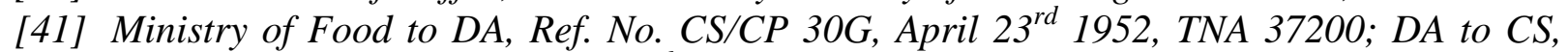
Ref. No. C/135/836, December $17^{\text {th }} 1946$, TNA 37200.

[42] Charlotte Leubuscher, (1956), pp.53-66.

[43] Government Notice No. 325, TNA 34953.

[44] DA to CS, Ref. No. 100/43, March 25 ${ }^{\text {th }}$ 1943, Cotton Control and Marketing during Wartime, TNA 34953.

[45] DA to CS, Ref. No. 100/42, March 25 ${ }^{\text {th }}$ 1942, TNA 34953

[46] DA to Lake Province Ginners Association, Ref. No. 252/5, January $22^{\text {nd }} 1943$, TNA 34953.

[47] Telegram CS Uganda to CS Tanganyika, December 17 $7^{\text {th }}$ 1942, TNA 34953; The Tanganyika Standard, December $2^{\text {nd }}$ 1941, TNA 28259/21; DA to CS, Ref. No. 1007/4839, October $2^{\text {nd }} 1941$, TNA 28259/21.

[48] DA to CS, Ref. No. 473/3878, July 23 ${ }^{\text {rd }} 1927$, TNA 34953.

[49] The Uganda Gazette, Vol. XXXVI, No. 13, January $12^{\text {th }} 1943$ (signed by Max Nurok - the deputy CS, TNA 34953; Members of the East African Exporters Group were Messrs Dakin Chairman), Collins, Paraschis, Paarekh, Clarke and Hassan Kassim) Tanganyika Standard, December 19 ${ }^{\text {th }}$ 1942, TNA 34953.

[50] The Defence Regulation (Control of Cotton) Order, 1943, TNA 34953.; Extracts from the meeting of the Cotton Board, held in Dar Es Salaam, May $4^{\text {th }}$ 1944, TNA 34953 Vol. II.

[51] CS Uganda to CS Tanganyika, December 17 ${ }^{\text {th }}$ 1942, TNA 34953 Vol. II.

[52] IBRD, The Economic Development of Tanganyika, (Baltimore: Johns Hopkins University Press, 1961), pp. 12, 13 and 202. 
[53] The World Bank, Tanganyika Agriculture and Rural Development Sector Study, Vol. II, December 10 ${ }^{\text {th }}$ 1974, (Baltimore: Johns Hopkins University Press), p. 4.

[54] Masao Yoshida, Agricultural Marketing Reorganisation in Post War East Africa, In Agricultural Marketing Intervention in East Africa: A Study in the Colonial Origins of Marketing Policies 1900 - 1965, (1980), pp. 252 - 254

[55] Government Notice No. 325, TNA 34953.

[56] DA to CS, Ref. No. 100/43, March 25 $5^{\text {th }}$ 1943, Cotton Control and Marketing during Wartime, TNA 34953.

[57] DA to CS, Ref. No. 100/42, March 25 th 1942, TNA 34953

[58] DA to Lake Province Ginners Association, Ref. No. 252/5, January 22 ${ }^{\text {nd }} 1943$, TNA 34953.

[59] Telegram CS Uganda to CS Tanganyika, December 17 $7^{\text {th }}$ 1942, TNA 34953; The Tanganyika Standard, December $2^{\text {nd }}$ 1941, TNA 28259/21; DA to CS, Ref. No. 1007/4839, October $2^{\text {nd }} 1941$, TNA 28259/21.

[60] DA to CS, Ref. No. 473/3878, July 23 ${ }^{\text {rd }} 1927$, TNA 34953.

[61] The Uganda Gazette, Vol. XXXVI, No. 13, January $12^{\text {th }} 1943$ (signed by Max Nurok - the deputy CS, TNA 34953; Members of the East African Exporters Group were Messrs Dakin Chairman), Collins, Paraschis, Paarekh, Clarke and Hassan Kassim) Tanganyika Standard, December 19 1942 , TNA 34953.

[62] The Defence Regulation (Control of Cotton) Order, 1943, TNA 34953.; Extracts from the meeting of the Cotton Board, held in Dar Es Salaam, May $4^{\text {th }}$ 1944, TNA 34953 Vol. II.

[63] CS Uganda to CS Tanganyika, December 17 $7^{\text {th }}$ 1942, TNA 34953 Vol. II.

[64] IBRD, The Economic Development of Tanganyika, (Baltimore: Johns Hopkins University Press, 1961), pp. 12, 13 and 202.

[65] The World Bank, Tanganyika Agriculture and Rural Development Sector Study, Vol. II, December 10 $0^{\text {th }}$ 1974, (Baltimore: Johns Hopkins University Press), p. 4.

[66] Masao Yoshida, Agricultural Marketing Reorganisation in Post War East Africa, In Agricultural Marketing Intervention in East Africa: A Study in the Colonial Origins of Marketing Policies 1900 - 1965, (1980), pp. 252 - 254

[67] The Long Term Contracts Policy on the United Kingdom Departments and Colonial Agriculture Producer, TNA 25147; Standard Newspaper September $28^{\text {th }} 1948$, TNA 25147.

[68] A Contract on the Local Arrangement for Handing of Ministry of Food Coffee, Director of East Africa Produce Disposal and Supply Council (Nairobi), March 13 ${ }^{\text {th }}$ 1947, TNA 37200.

[69] Extract from minute of meeting of the standing committee held in April 1947, TNA 11969.

[70] DA to CS, Ref. No. C/133/330, December, 17 $7^{\text {th }}$ 1942, TNA 37200; Ministry of Food to CS, Telegram, No. WB/293, November $21^{\text {st }}$ 1946, TNA 37200.

[71] KNCU to Ministry of Food, TNA 37200.

[72] East Africa High Commission, London to East Africa Joint Economic Commission (Nairobi) Confidential Telegram, Ref. No. 4142/458, October 28 th 1949, TNA 37200.

[73] KNCU to Ministry of Food, TNA 37200.

[74] One of the causes for the sterling depreciation in terms of United States of America (USA) dollar was economic slowdown, economic depression in the USA and capital flight in Britain as a result of the Second World War that sterling pound sharply depreciated to $\$ 4.03$. 
[75] Tanganyika Legislative Council Debates, Hansard, 1950, $29^{\text {th }}$ Session, para. 241, TNA 37200.

[76] The Decontrol of Coffee, Press Notice by Ministry of Food August 20 ${ }^{\text {th }}$ 1952, TNA 37200.

[77] The Decontrol of Coffee, Press Notice by Ministry of Food August 20 th 1952, TNA 37200.

[78] USDA, United Kingdom Market for United States Agricultural Products Agriculture Information Bulletin No. 104, (Washington, D. C.: The USA Government Printing Office, 1953), p.56.

[79] The Long Term Contracts Policy on the United Kingdom Departments and Colonial Agriculture Producer, TNA 25147; Standard Newspaper September $28^{\text {th }} 1948$, TNA 25147.

[80] A Contract on the Local Arrangement for Handing of Ministry of Food Coffee, Director of East Africa Produce Disposal and Supply Council (Nairobi), March 13 ${ }^{\text {th }}$ 1947, TNA 37200.

[81] DA to CS, Ref. No. C/133/330, December, 17 th 1942, TNA 37200; Ministry of Food to CS, Telegram No. WB/293, November $21^{\text {st }}$ 1946, TNA 37200.

[82] The Decontrol of Coffee, Press Notice by Ministry of Food August 20 th 1952, TNA 37200.

[83] Ministry of Food to DA, Ref. No. CS/CP 30G, April 23 rd 1952, TNA 37200; DA to CS, Ref. No. C/135/836, December $17^{\text {th }} 1946$, TNA 37200.

[84] Charlotte Leubuscher, (1956), pp.53-66.

[85] Government Notice No. 325, TNA 34953.

[86] DA to CS, Ref. No. 100/43, March 25 $5^{\text {th }}$ 1943, Cotton Control and Marketing during Wartime, TNA 34953.

[87] DA to CS, Ref. No. 100/42, March 25 ${ }^{\text {th }}$ 1942, TNA 34953

[88] DA to Lake Province Ginners Association, Ref. No. 252/5, January 22 ${ }^{\text {nd }} 1943$, TNA 34953.

[89] Telegram CS Uganda to CS Tanganyika, December 17 $17^{\text {th }} 1942$, TNA 34953; The Tanganyika Standard, December $2^{\text {nd }} 1941$, TNA 28259/21; DA to CS, Ref. No. 1007/4839, October $2^{\text {nd }} 1941$, TNA 28259/21.

[90] DA to CS, Ref. No. 473/3878, July 23 ${ }^{\text {rd }} 1927$, TNA 34953.

[91] The Uganda Gazette, Vol. XXXVI, No. 13, January $12^{\text {th }} 1943$ (signed by Max Nurok - the deputy CS, TNA 34953; Members of the East African Exporters Group were Messrs Dakin Chairman), Collins, Paraschis, Paarekh, Clarke and Hassan Kassim) Tanganyika Standard, December 19 $9^{\text {th }}$ 1942, TNA 34953.

[92] The Defence Regulation (Control of Cotton) Order, 1943, TNA 34953.; Extracts from the meeting of the Cotton Board, held in Dar Es Salaam, May $4^{\text {th }}$ 1944, TNA 34953 Vol. II.

[93] CS Uganda to CS Tanganyika, December 17 th 1942, TNA 34953 Vol. II.

[94] IBRD, The Economic Development of Tanganyika, (Baltimore: Johns Hopkins University Press, 1961), pp. 12, 13 and 202.

[95] The World Bank, Tanganyika Agriculture and Rural Development Sector Study, Vol. II, December 10 $0^{\text {th }}$ 1974, (Baltimore: Johns Hopkins University Press), p. 4.

[96] Masao Yoshida, Agricultural Marketing Reorganisation in Post War East Africa, In Agricultural Marketing Intervention in East Africa: A Study in the Colonial Origins of Marketing Policies 1900 - 1965, (1980), pp. 252 - 254 